In conclusion, the OECD considers the expected implementation of the REGIO-Plus Programme to be an appropriate and necessary addition to Switzerland's present array of regional policy tools. It should be a means of answering the challenges facing rural communities while at the same time fulfilling the expectations of society as a whole where rural areas are concerned.
Christian HuIllet, Acting Head Rural Development Programme $O E C D$

2 Rue André-Pascal 75775 Paris Cedex 16 France.

\title{
Wetlands of Uruguay Threatened Again by Inappropriate Development
}

$\mathrm{H}$ eedless development of two sorts threatens the survival of the Rocha coastal wetlands, which are said to be the second largest in the Americas after the Florida Everglades. The Uruguayan Department of Rocha lies immediately south of the southernmost end of the coast of Brazil, the border town of Chui being $340 \mathrm{~km}$ ENE of Montevideo. Prominent among Rocha's topographical features were four big freshwater lagoons that opened occasionally to the sea after heavy storms. Bordering these lagoons were some half-million hectares of wetlands that were recognized by 150 signatory countries to the 1982 Ramsar Convention as being of critical international importance.*

Six years earlier, Uruguay had formally accepted inclusion of these wetlands in UNESCO's Man and the Biosphere (MAB) Programme. Uruguay is a signatory to the Washington Convention of 1969 for the protection of fauna and flora and areas of especial natural scenic importance, and also to the Bonn Convention of 1989 for the conservation of migratory species of wild animals. Uruguay strongly supported the Rio Declaration of 1992, one of four main thrusts of the UN Conference on the Environment and Development being the safeguarding of biodiversity.

Wetlands are now recognized as being among the richest in species diversity of all fish and wildlife habitats. The wetlands of Rocha, or Banados del Este as they are called locally, support a great diversity of flora and fauna, including at least 120 species of waterbirds, 80 of fish, and 30 of amphibians. They are believed to be vital to the winter migrations of a dozen species of Arctic birds and a much larger number of Antarctic species.

Rationalizing that the wetlands of Rocha are one of the most environmentally diverse natural habitats in the world, as well as one of the least known, the Global Environment Facility (a financial 'window' of the World Bank) is funding a United Nations Development Programme project to assist Uruguay to construct and operate a wetlands research institute in Rocha.

\section{Road Construction Threat to Lagoon}

Seeking to serve the developers of tourist facilities and beach homes as they expand rapidly eastwards from Punta Del Este, the Government of Uruguay has announced its intention to shorten the distance to La Paloma by constructing a causeway joining the two arms of the Rocha

* Ramsar is the name of a town in Iran which, under prompting by Dr Eskandar Firouz, agreed to host an IUCN (International Union for Conservation of Nature and Natural Resources, now named the World Conservation Union) conference on migratory bird species' survival.
Lagoon. This would allow the sea to have tidal access into the Lagoon and its freshwater values would be forever lost, repeating stupefyingly what happened under similar circumstances to Garzon Lagoon only a few years ago. Since Laguna Negra is drying out as a consequence of the introduction of rice-growing, there would then be left only Laguna de Castillos as the last of the freshwater lagoons in the country.

\section{Rice-growing Again Threatens More Wetlands}

Making use of the wetlands water in Rocha for ricegrowing was started in the late 1970 s by a consortium of large companies and banks at an unusual time in Uruguay, when the country was under a military junta and starved of foreign exchange. Ten years on, the companies involved began to understand from declining yields that they would do better to move to less low-lying lands. A dam in the middle of Rocha having the capacity to irrigate 10,000 hectares is being used for only one-third of that amount, as I saw last November from the window of a small aeroplane belonging to one of the rice-growing companies. The ecological cost has been the loss of more than a quarter of the wetlands.

During the course of several conversations with Dr Enrique Zunini Fernandez, a veterinarian and President of the Comision de Flora Y Fauna, Sociedad Ecologica Rochiense, I learned that the Government has plans, already approved by Assembly decree, to canalize yet more water in the wetlands. One scheme, that is masquerading as a public benefit, is for diverting drainage water from polluting a beach by lifting it away into Lake Mirim, most of which lies in Brazil. The above-mentioned Dr Zunini has written a paper stressing the absurdity of official persistence in promoting investment-intensive, mechanized rice-growing in areas that have already proved to be unsuitable for viable commercial rice production.

In Environmental Conservation's 1994 Spring issue, there appeared a Note heralding the establishment of a Secretariat for the Ramsar Convention in Gland, Switzerland. Hopefully, it will have received a copy of Dr Zunini's paper and gone into action to arouse attention to the possibility that Uruguay may be about to disregard quite flagrantly its responsibilities for the safeguarding of the wetlands of Rocha.

PHILIP B. THRESHER
Juan Crespi Lane
Santa Barbara
California $93150-0018$
USA.

PHILIP B. THRESHER USA

\section{Advances in Ecology for Population and Community Specialists}

$\mathrm{O}$ ne of the most exciting current developments in population and community. ecology is the increasing integration of theoretical and empirical studies. This is eroding the barriers between the largely separate traditions of theoretical, experimental, and field, ecology which have developed through much of this century. These advances are happening at an opportune time in that there is an urgent need for a more analytical understanding of the dynamics of natural systems - to lessen the impact of human activities, to sustain renewable resources, and to exploit the 